Claremont Colleges

Scholarship@ Claremont

All HMC Faculty Publications and Research

HMC Faculty Scholarship

4-1-2014

\title{
Aftermath: Every Math Major Should Take a Public-Speaking Course
}

Rachel Levy

Harvey Mudd College

\section{Recommended Citation}

Levy, Rachel. "AFTERMATH: Every Math Major Should Take a Public-Speaking Course." Math Horizons 21.4 (April 2014): 34. doi: 10.4169/mathhorizons.21.4.34

This Article is brought to you for free and open access by the HMC Faculty Scholarship at Scholarship @ Claremont. It has been accepted for inclusion in All HMC Faculty Publications and Research by an authorized administrator of Scholarship @ Claremont. For more information, please contact scholarship@cuc.claremont.edu. 
AFTERMATH: Every Math Major Should Take a Public-Speaking Course

Author(s): Rachel Levy

Source: Math Horizons, Vol. 21, No. 4 (April 2014), p. 34

Published by: Mathematical Association of America

Stable URL: http://www.jstor.org/stable/10.4169/mathhorizons.21.4.34

Accessed: 21/04/2014 17:14

Your use of the JSTOR archive indicates your acceptance of the Terms \& Conditions of Use, available at http://www.jstor.org/page/info/about/policies/terms.jsp

JSTOR is a not-for-profit service that helps scholars, researchers, and students discover, use, and build upon a wide range of content in a trusted digital archive. We use information technology and tools to increase productivity and facilitate new forms of scholarship. For more information about JSTOR, please contact support@jstor.org. 


\section{Every Math Major Should Take a Public-Speaking Course}

\section{RaChel LeVY}

n mathematics courses we practice deep thinking, clear writing, and effective problem solving. Excellent public speaking complements these skills. As one of my students put it:

No matter what we all do after college ... [we] will have to speak to people. Every one of us will have a limited amount of time that we can convince someone else to see our point of view.

A public-speaking course can help you develop a superpower: the ability to communicate to a live audience in a clear, compelling manner. Every mathematics major should take such a course. Comments in italics are from my students in Math Forum, our required public speaking course at Harvey Mudd College.

Unfortunately, standing up in front of a group makes us nervous. Our hearts beat faster; this throws off our body chemistry and can make us feel ill. We fidget, rock back and forth, make awkward hand gestures, or stand unnaturally still. Our body language, voice inflection, and gestures reveal our discomfort.

There's something fundamentally nerve-racking about giving a presentation. The first day of Math Forum, we all attempted to describe that near-indescribable feeling of speaking in front of an audience. . . Here I was, in a class that I had dreaded taking since hearing about it my freshman year, thinking I was the only person that had these feelings, . . . and yet the dozen other people in the class shared this same feeling.

Practice is key to taming our nervousness and to making a successful presentation.

With each talk I delivered throughout the semester, my confidence only increased. For my first talk, I was a nervous speaker that feared the whole ordeal, unable to deliver my opinions with sincere confidence. In contrast, for my last 10-minute talk, I was completely comfortable and calm. I had even begun to enjoy interacting with the audience during the presentation.

We can learn a lot from watching other speakersprofessors, renowned lecturers, and classmates. If possible, watch yourself giving a presentation.

In re-watching the video of my second talk, . . . I noticed I sometimes shifted my body weight from one side to the other. . . . In my [later] talk, I felt at ease, and this was evident in my posture.

Careful preparation is essential to a first-rate lecture.
Speaking tasks often have a fixed, typically short, time allotment. In a public-speaking course, you learn to deliver a message within a given time and to pare your

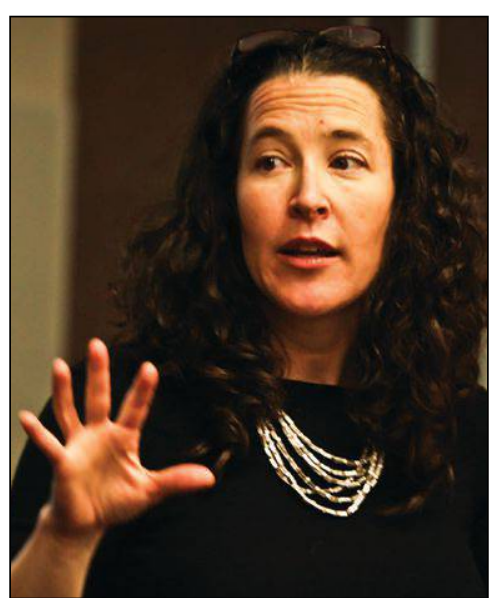

Rachel Levy. talk down to its essence, so that there is no wasted moment. Although there are many ways to construct a successful presentation, you'll learn how to write a strong introduction and conclusion, and how to connect them with a logical flow of ideas.

Written mathematics can be expressed elegantly and efficiently with words and symbols, but in a presentation, written words and complicated mathematical notation are difficult to follow. A lecture benefits from an effective use of images, clever uses of color, and careful placement of choice information for each slide. Generally: Less is more.

These are a small sampling of the many skills you will learn in public-speaking class. If no such class is available, consider other options, such as a theater class or a Toastmasters club; research groups and math clubs can also provide opportunities for you to give a presentation. These experiences can help you deliver confident, compelling communication about any topic, including mathematics.

I got a glimpse at the sorts of strategies I'll need to give good talks: approaching a topic from the eyes of someone who is unfamiliar with it, eschewing notation unless it is particularly elucidating, leaving out ideas that don't support whatever central message I want to present, and many more. . . I am happy I was able to share the ideas I find interesting with the rest of my Forum class. It was unbelievably satisfying to finally give a talk I could be proud of.

Rachel Levy is an associate professor of mathematics at Harvey Mudd College and editor-in-chief of SIAM Undergraduate Research Online (SIURO).

Email: levy@hmc.edu

Aftermath essays are intended to be editorials and do not necessarily reflect the views of the MAA. To respond, go to horizonsaftermath.blogspot.com.

http://dx.doi.org/10.4169/mathhorizons.21.4.34 